\title{
Vyf en twintig jaar kerkreg binne die ruimte van die Nederduitsch Hervormde Kerk van Afrika*
}

\author{
AD PONT
}

\section{INLEIDENDE OPMERKINGS}

Die vak Kerkreg word vanaf 1921 op 'n vaste basis aan die teologiese opleiding van die Nederduitsch Hervormde Kerk van Afrika gedoseer. In 1921 is SP Engelbrecht aangestel om Kerk- en Dogmengeskiedenis te doseer. Van kerkweë het hy toe ook opdrag gekry om die kerkreg te versorg. Hierdie vakopdrag het ek in 1957, as opvolger van Engelbrecht, net so oorgeneem.

Die vak Kerkreg is van die begin af by die historiese vakke in die teologiese leergang gereken. In die verbygaan kan vermeld word dat geen uitgesproke motivering van die kant van die kerklike instansies vir hierdie reëling gevind kon word nie. Tog is dit nie moeilik om te sien waarom die vak Kerkreg by die historiese vakke gegroepeer moet word nie. Dit dan veral vir twee redes:

Die eerste is dat by die doseer van die vak Kerkgeskiedenis, baie afhang van die omskrywing van die begrip kerk. Die dogmatiese omskrywing van die begrip, soos dit onder andere in die Nederlandse Geloofsbelydenis gevind kan word, bepaal die prinsipiële inhoud van die begrip kerk. Maar, en dit is seker nie toevallig nie, die reformatoriese vadere het, soos in Frankryk in 1559, met die bekendstelling van die Confession de Foi, graag 'n kerklike orde as 'n omskrywing van die praktiese orde en struktuur van die kerk, op die geloofsbelydenis laat volg (vgl. Niesel sa: 136). Die begrip kerk was en is, in die reformatoriese kerk en teologie, nooit 'n eksklusiewe dogmatiese nie, maar altyd óók 'n kerkordelike en kerkregtelike begrip ${ }^{1}$.

Omdat in die studie van die kerkgeskiedenis die aandag hoofsaaklik op die sigbare, georganiseerde kerk gevestig is, is dit vanselfsprekend dat die ordening en struktuur van die kerk en die kerklike reg vir die kerkgeskiedenis van wesenlike belang is.

Die tweede rede lê daarin dat die kerklike orde en reg, naas die bron van die Heilige Skrif, ook put uit die bron van die voortdurende gewoonte wat in die kerklike lewenspraktyk geld. Dit beteken dat die Kerkreg 'n vak met 'n sterk historiese inslag en bepaaldheid is. Vanselfsprekend bring dit die Kerkreg in die eerste plek in die

* Referaat gelewer by die Kongres van die Kerkhistoriese Genootskap, November 1982. 
kring van die historiese vakke. Sonder kennis van die geskiedenis van die kerk en sy leer word die beoefening van hierdie vak nogal moeilik.

Vanuit dié twee oorwegings alleen al, is dit volkome regverdigbaar dat die Kerkreg by die historiese vakke ingedeel is en in die afgelope sestig jaar het dit die beoefening van die vak in ons opleiding sekerlik gebaat.

Miskien is dit, en dit dan net terloops, tog merkwaardig dat in die kring van ons kerk die vak Kerkreg deurentyds deur teoloë hanteer is. In die NG Kerk is daar, interessant genoeg, ook 'n gebruik dat die Kerkreg as 'n juridiese vak behandel word. Hoewel daar wel iets ten gunste daarvan gesê kan word, bly dit egter waar dat die Kerkreg primêr ' $n$ teologiese vak is, want dit soek altyd na 'n duidelike Skriftuurlike fundering. Daarmee word juis, teenoor die juridiese wetenskap die eiesoortigheid van die kerklike reg beklemtoon. Immers dit is wel 'n vraag of die kerklike reg inderdaad reg is in die sin waarin die juriste die begrip hanteer. Dit lyk, gesien die Skriftuurlike basis en inhoud van die Kerkreg, enigermate problematies. Tog moet toegegee word dat die beoefening van die Kerkreg vanuit 'n juridiese agtergrond nie volkome sonder meriete is nie, aangesien die landsreg tog rondom die kerk-as-liggaam in die wêreld bestaan.

Die gebruik in ons kerk is egter om die vak Kerkreg as voluit teologiese vak te hanteer en dit is 'n besluit wat nie alleen gehandhaaf moet word nie, maar wat ook die inhoud en kwaliteit van die vak bepaal.

\section{DIE PERIODE 1921-1956}

Gedurende die 35 jaar wat prof SP Engelbrecht die vak Kerkreg hanteer het, is dit ook bepaal deur die feit dat hy in sy wetenskaplike werkverrigting uitgegaan het van die opvatting dat hy ons kerk in alles en teenoor almal moet verdedig. Hierdie opvatting, wat in die vroeë dekades van ons eeu heeltemal verstaanbaar en selfs noodsaaklik was, het egter ook nadele ingehou. Dit het meegebring dat Engelbrecht betreklik onkrities gestaan het teenoor die kerklike orde wat vanaf 1836 tot 1950 in ons Kerk gegeld het. Die feit dat dié verskillende kerklike ordes vir 'n baie groot deel gebou was op die Kaapse kerkwette van 1824 en 1842 en die Nederlandse kerkordelike denke na 1816, het daaraan nie veel verander nie. Hoewel Engelbrecht hoë waardering gehad het vir die uitnemende werk van HG Kleijn, Algemene kerk en plaatselijke gemeente, Dordrecht 1888, het hy nie raakgesien nie dat die verenigingsreg, soos dit in Nederland na 1816 onder invloed van die verligte denkers na vore gekom het, op baie punte die reformatoriese kerkreg deurkruis het. Vandaar ook dat die debat tusen hom en ds JV Coetzee van die Gereformeerde 
Kerk in die veertigerjare nie veel positiefs opgelewer het nie. Immers die standpunte van die twee teenstanders het taamlik ver van mekaar af gelê en nie een van die twee was besonder geneë om die ander se standpunt te probeer verstaan nie ${ }^{2}$.

Uit die polemiek het dit wel duidelik geword dat Engelbrecht geen waardering vir die Doleansie-kerkreg ${ }^{3}$, soos dit in die vorige eeu in Nederland ontwikkel is, gehad het nie. Andersyds het hy ook nie veel meer gedoen as om sommige standpunte van $\mathrm{Ph} J$ Hoedemaker en sy navolgers weer na vore te bring nie. Dit het 'n sekere onwerklikheid aan dié debat gegee omdat die Nederlandse situasie as die geldende beskou is (vgl. Engelbrecht 1945: $39 \mathrm{vv}$ ). Daarby was dit duidelik dat Engelbrecht, waarskynlik vanweë sy afwysing van die Doleansiekerkreg, te min waarde geheg het aan die vormgewing van die kerklike orde soos dit deur Joh Calvyn na vore gebring is en daarna, deur die reformatoriese vadere vanaf die Sinode van Emden 1572 in Nederlandse konteks geplaas is.

Uit Engelbrecht se enigsins driftige polemiek met Coetzee èn uit die geheel van sy nagelate geskrifte word dit duidelik dat hoewel Engelbrecht die vak Kerkreg in die opleiding hanteer het en hy geweldig baie van die historiese materiaal beheers het, die vak as sodanig nie in die sentrum van sy belangstelling gestaan het nie ${ }^{4}$. Tog het hy deur sy publikasies en as jarelange lid van die kerk se Raad vir Regsadvies sy bydrae op hierdie vlak gelewer. Hy het ook sy rol gespeel om die Kerkwet van 1869, wat met wysigings bly geld het tot in 1950, in 1951 met 'n nuwe Kerkwet te laat vervang wat op die lees van die kerkorde van die Nederlandse Hervormde Kerk van 1950 geskoei was.

\section{VANAF 1957}

Toe ek in 1957 begin het om Kerkreg te doseer, was dit vir my opvallend hoe min gepubliseerde materiaal uit ons eie Kerk beskikbaar was. Dit het die indruk verstewig dat ons, wat die Kerkreg betref, ons materiaal hoofsaaklik uit Nederland betrek het. Dit het meegebring dat daar nie juis 'n poging was om self op hierdie gebied navorsing te doen en te publiseer nie. Sodoende moes daar teruggeval word op die werk van Nederlandse teoloë en kerkregdeskundiges. Dit is indertyd byna as vanselfsprekend aanvaar daar toe nog betreklik noue bande met die Nederlandse Hervormde Kerk en die teologiese fakulteite aan die universiteite aldaar gehandhaaf is. Met die geleidelike versosiosialisering en politisering van die Nederlandse Hervormde Kerk, het dit egter vir ons kerk al meer sinloos geword om daardie betrekkinge te bly handhaaf.

In ieder geval was daar in die laat vyftigerjare nogal 'n ryk oes aan kerkregtelike publikasies in Nederland. Dit het saamgehang met die uitvoerige navorsing wat gedoen is om aan die Nederlandse Her- 
vormde Kerk 'n nuwe kerklike orde en struktuur te gee wat die uitgediende 1816-patroon moes vervang ${ }^{5}$. Ook in die Duitse en Switserse teologie is onder die invloed van die Dialektiese Teologie en die kerklike en kerkregtelike ontwikkelinge in Duitsland vanaf 1933, heelwat aandag aan die kerklike orde en reg gegee.

Tog was dit van die begin af duidelik dat nie alles wat dáár gepubliseer is, sonder meer op ons in ons kerklike situasie toepasbaar was nie. Ons posisie hier in Suid-Afrika en alles wat dit meegebring het, het beteken dat baie van die Europese publikasies slegs indirek vir ons bruikbaar was. Die kerkregtelike vraagstukke waarmee ons in ons Kerk moes worstel, was anders as dié in Nederland. Dit het al gou vir my duidelik geword toe ek 'n eerste poging moes aanwend om iets op die terrein van die kerklike orde te sê. Dit was toe die Predikantevergadering van 1958 my gevra het om iets oor artikel III en die kerklike orde te sê. Dié uiteensetting was die aanleiding tot' $n$ taamlike woordewisseling juis omdat ek nié sonder meer in die voetspoor van (linkse) Nederlandse eksegete en kerkregtelikes en hulle napraters in Suid-Afrika wou loop nie.

In ieder geval, toe ek in 1957 met die doseerwerk in die vak Kerkreg begin het, was dit vir my duidelik dat die grondslae en inhoud van die vak eers weer sorgyuldig nagevors moes word. Daar moes ' $n$ fondament gebou word waarop daar mettergaan voortgebou kon word. Dit moes, soos verstaan kan word, onder 'n redelike mate van druk geskied. Dit het nie altyd so maklik gegaan nie, want in die voetspoor van my voorganger, moes ek ook nog lesings op die vakgebied van die Algemene Kerkgeskiedenis, die Dogmengeskiedenis, die Nederlandse en die vaderlandse kerkgeskiedenis aanbied.

Wat die Kerkreg betref was daar, so het ek dit gesien, net een uitweg en dit was om histories te werk te gaan en om uit daardie hoek oor die oorspronge en grondslae van die vak navorsing te doen. Gelukkig was dit, vanweë die Kerkhervorming, nie nodig om verder terug te gaan as tot by die kerkordenende werk van die kerkvader Joh Calvyn en sy inrigting van die kerk in Genève nie. Daarvandaan moes die kerkordelike beginsels en die vormgewing van die kerklike struktuur nagevors word in Frankryk en dan weer soos dit via Frankryk en die Nederlandse vlugtelinggemeentes deurgedra is na Nederland. Daar in Nederland het die calvinistiese kerklike orde, soos dit spesifiek by die Sinode van Emden 1572 geformuleer is, bepalend geword vir die Nederlandse kerkordelike tradisie wat tot 1816 geleef het.

Tog was daar in hierdie navorsing struikelblokke genoeg, veral om die tekste van die ou kerkordes te bekom. Dit was tydens dié soektogte dat die gedagte ontstaan het om nog eendag 'n publikasie die lig te laat sien wat die belangrikste calvinistiese kerkordes, wat vir ons kerk veral ter sake is, beskikbaar sou stel. Die feit dat dit tot 1981 
geduur het voordat dit moontlik was, toon wel dat dit net nie moontlik was om onverdeelde aandag aan dié projek te gee nie.

Die gunstige ontvangs wat die eerste deel van my Die historiese agtergronde van ons kerklike reg, 1981 te beurt geval het, was wel 'n voldoening, veral omdat die RGN, wat ek by geleentheid vir steun genader het, geoordeel het dat hierdie werk nie in "nasionale belang" is nie!

Die opvolgende deel van Die historiese agtergronde wat die geskiedenis van ons kerkordenende denke van 1652 tot 1951 beskrywe en ook ' $n$ hele aantal tekste bevat, is feitlik voltooi. Daarmee sal die groot lyne van die geskiedenis navolgbaar wees en sal dit dus moontlik wees om met betreklike gerief die "voortdurende gewoonte" van die kerk na te speur.

Tog beteken dit nie die einde van die werk nie, want heelwat studie van besonderhede moet nog gedoen word. Met die publikasie van die verskillende kerkordes of kerkwette is alles nog nie gesê nie. Die volgende vraag is hoe die verskillende vergaderings van die ampte die geformuleerde standpunte toegepas en uitgeleef het, en verder hoe dit die kerklike lewe en veral die regte kerklike verkondiging van die Woord gedien of belemmer het. Alleen deur die opvolgende studie sal die geskiedenis wat op hierdie vakgebied geld, enigsins volledig wees. Hopelik sal daar navorsers na vore kom wat die tyd en geleentheid sal hê om aan hierdie studie aandag te gee.

In die verbygaan is dit tog noodsaaklik om 'n oomblik oor die kerklike muur te loer om op dié manier daarop te wys dat ook in die ander twee Afrikaanse kerke werk op die vlak van die Kerkreg gedoen is en gedoen word, wat nié verbygegaan kan word nie.

Veral van NG-kant het 'n aantal publikasies die lig gesien wat van waarde is vir die geskiedenis van die kerklike ordeningspatrone hier in Suid-Afrika. Hier bedoel ek dan veral die werk van JD Vorster, Die kerkregtelike ontwikkeling van die Kaapse Kerk onder die Kompanjie, 1652-1795, Potchefstroom 1965 asook dié van EPJ Kleynhans, Die kerkregtelike ontwikkeling van die Nederduitse Gereformeerde Kerk in Suid-Afrika, 1795-1962, Stellenbosch 1973. Daarnaas kan ook verwys word na die ongepubliseerde DD-proefskrif van FAH van Staden, Kerkorde in die geskiedenis van die Nederduitse Gereformeerde Kerk in Suid-Afrika 1652-1970, Universiteit van Pretoria 1973. Daarby is die ouer werk van JP Jooste, Die verhouding tussen kerk en staat aan die Kaap tot die helfte van die 19de eeu, Bloemfontein 1964, nog steeds van belang. Op hierdie terrein is die werk van PB van der Watt, Die Loedolffsaak en die Nederduitse Gereformeerde Kerk 1862-1962, Kaapstad 1973, ook interessant. Hierdie verskillende werke het oor die algemeen min bekendheid in ons kerklike kringe. Sou dit saamhang met die opvatting (of is dit 'n misvatting?) dat die studie van die kerkreg so tegnies is dat dit nie aan 'n gewone sterfling gegee is om 
dit te beoefen nie? Niks kan verder van die waarheid wees nie omdat die Kerkreg juis te make het met die daaglikse lewe en werk van die kerk en daarom vir elkeen van belang is.

Daarom kan die publikasie van EPJ Kleynhans, Gereformeerde Kerkreg, Deel 1 Pretoria 1982, ook genoem word. Hierin volg Kleynhans die spoor van $\mathrm{H}$ Bouwman, die Nederlandse Gereformeerde kanonikus, wie se tweedelige Gereformeerd Kerkrecht, lank as die enigste volstandige naslaanwerk op dié gebied gegeld het. Dit is te hope dat Kleynhans die geleentheid sal hê om sy werk te voltooi, want in Suid-Afrika bestaan daaraan beslis ' $n$ behoefte. Dan is daar ook die belangrike prinsipiële werk van GPL van der Linde, Grondbeginsels van die presbiteriale kerkregeringstelsel, Potchefstroom 1965.

\section{ENKELE OPMERKINGS OOR DIE GRONDSLAE VAN DIE KERKREG}

Dit is so, soos reeds betoog, dat as die historiese studie ten opsigte van die kerklike ordes afgehandel is, dit nié die einde van die vak Kerkreg beteken nie. Daarop volg die navorsing en vasstelling van die Skriftuurlike en dogmatiese basis vir al die kerklike formulerings. Hierdie aspek van die Kerkreg is nie alleen ' $n$ besonder interessante navorsingsveld nie, maar ook verrykend. Van belang is om te konstateer dat op hierdie terrein, gedurende die afgelope aantal jare 'n aantal belangrike publikasies buite ons kerk se kring verskyn het, (vgl. o.a. Milner 1970; Plomp 1969; Van 't Spijker 1970).

Op hierdie vlak is die vraag na die Skriftuurlike basis van die kerklike orde van wesenlike belang. Dit is dan die vraag of die kerklike orde, wat sy groot lyne betref, Skriftuurlik is of nie en anders die vraag of dit noodsaaklik is dat dit Skriftuurlik moet wees of nie. Hier kom dus die vraag na vore of die kerklike orde ius divinum is of moet wees, of is dit ius humanum of 'n vermenging van altwee? 'n Belangrike vraag is dan ook wat onder dié twee begrippe verstaan moet word.

Aan die een kant word die noodsaaklikheid gestel dat die basiese beginsels van die kerklike orde suiwer Skriftuurlik is en moet wees. Dit is ' $n$ argument wat veral in die calvinistiese kerke gedurende die 17 de eeu na vore gebring is. Dit is bekend dat die Westminster Assembly veral baie moeite gedoen het om die Skriftuurlik-bepaalde kerklike orde vas te stel in 'n stuk wat getitel is: The form of Presbyterial church-government and of ordination of ministers. Hier word, byvoorbeeld met taamlik baie besonderhede die Skriftuurlike basis vir die presbiteriaal-sinodale kerklike orde uiteengesit. Hierdie standpunte is, gedurende die $19 \mathrm{de}$ eeu, deur die manne van die Doleansiekerkreg in Nederland weer na vore gebring. Met hierdie stand- 
punt word die kerkorde dan nie net 'n aanhangsel van die geloofsbelydenis nie, maar feitlik deel daarvan.

Die opvatting wat die ander uiterste verteenwoordig, word in die $19 \mathrm{de}$ eeu na vore gebring wanneer gestel word dat die kerk in wese 'n geloofsgemeenskap is en dat daardie geloofsgemeenskap nie deur kerklike bepalings en verordeninge in 'n sigbare organisasie saamgevat kan word nie ${ }^{6}$. Dit het saamgeval met die opkoms en verbreiding van die antroposentriese teologie van die Verligtheid ("Aufklärung") waar die sigbare kerk slegs as 'n menslike vrywillige vereniging verstaan is.

Dit is duidelik dat altwee hierdie standpunte, in hulle ekstreme vorm, probleme skep. Maar dit beteken nog nie dat gesê kan word dat die hele saak van die kerklike orde ' $n$ indifferente aangeleentheid is wat maar pragmaties, volgens die eise van die omstandighede, gereël moet word nie. Hierdie opvatting wat te veel in ons kerk gestel word, skep verkeerdelik die indruk dat die kerklike orde nie 'n voldoende Skriftuurlike basis het nie. Hierdie negering van die Skrif as die vaste basis vir die kerklike orde en regering is in ons tyd nie meer houdbaar nie. Tog moet daar ook gewaak word teen die opvatting dat die kerklike orde en regering deel van die wese van die kerk is. Die kerklike orde dien die wel-wese van die kerk. As dit sterker gestel word, word die onaanvaarbare Roomse opvatting aan die orde gestel.

Lángs hierdie vraag na die verhouding tussen Skrif en kerklike orde, wat in ons interne kerklike gedagtewisseling nog maar min aandag ontvang het, kom dan ook nog die verdere vrae na vore oor die inhoud en strekking van die amp, die wese en funksie van die vergaderings van die ampte en wat alles deur die kerklike dissipline of tug bedoel word. Hiér bestaan by ons die probleem dat die 19deeeuse verenigingsreg, asook die invloed van die sekulêre wêreld en reg, juis deur middel van ons vroeëre kerkwette voor 1951, veroorsaak het dat die oorspronklik-reformatoriese en Skriftuurlike beginsels wat hierdie begrippe aanvanklik gevul het, op die agtergrond geraak het.

'n Groot mate van die "verwarring" en "misverstand" rondom die amp, waarna soms in ons kerklike lewe verwys word, hang saam met die feit dat die diens-amp met sy inherente leer- en regeeropdragte nie Skriftuurlik nie, maar vanuit die dinkwêreld van die verenigingsreg uitgelê en verstaan is. Die hele verskraling van die amp van die diaken en ' $n$ groot deel van die verwarring wat op die vlak van die barmhartigheidsdiens geheers het, moet hieraan toegeskryf word.

Dit is egter opvallend dat die verskillende kerkordelike vrae rondom die amp en die vergaderings van die ampte in ons teologiese arbeid nie veel aandag gekry het nie. Daarteenoor is in die kring van 
die NG Kerk en die Gereformeerde Kerk heelwat studie- en navorsingswerk hieraan gewy ${ }^{7}$. Dit kan beteken dat, wanneer in 1983 oor die verkleining van die Algemene Kerkvergadering gehandel word, die nodige diepgang in die diskussie kan ontbreek. Hopelik sal dit nie beteken dat die pragmatiese benadering, wat gewoonlik met blinde oë na die verlede en die Skriftuurlike grondslae van die kerklike orde en reg kyk, hierin die oorhand sal kry nie.

Die vrae rondom die dissipline, oftewel die tug, in die kerk het gedurende die laaste paar jaar weer sterker na vore gekom. Interessant genoeg het ons kerk in sy geskiedenis altyd sterk klem op die regte prediking en die handhawing van die suiwere leer laat val ${ }^{8}$. In ons tyd het die klem wat op die apostolaat van die kerk gelê word, die noodsaak om die suiwere leer en lewenswandel te handhaaf ook beteken dat opnuut na die dissipline van die kerk gekyk is.

Dit is nie net in ons kerk waar die vrae rondom die dissipline na vore kom nie. Van NG kant bestaan daar die werk van WD Jonker, En as jou broer sondig, Pretoria s.a. In die Gereformeerde Kerk het onlangs die D Th proefskrif van J Visser, Die tug oor die ampsdraers, PU vir CHO 1982 verskyn. By Visser word veral die problematiek behandel van die tugreg van die meerdere vergaderings oor ampsdraers wat aan die outonome plaaslike kerk verbonde is. Dit bring dus mee dat die probleem wat die begrip kerkverband daar en elders opwerp, goed besien word.

Miskien vir ons ietwat meer bruikbaar is die belangrike ondersoek van TNH Sadler, Die kerklike tughandeling, DD proefskrif, Universiteit van Pretoria 1978. Hoewel Sadler vanuit die NG kerkregtelike tradisie skryf, is heelwat van sy navorsing van wesenlike belang. Dit veral omdat hy die probleem hanteer dat die landsreg die kerk as 'n vrywillige vereniging beskou en behandel. Hier word die saak van die verhouding tussen kerk en staat enersyds en die kerklike reg en die landsreg andersyds deeglik aangesny. Tereg blyk dit dat die tipiese 19de-eeuse gesekulariseerde en verligte denke die landsreg bepaal, wat op sy beurt beteken dat die kerk en sy werk dáár volkome misverstaan word.

Hierdie werke wat oor die dissipline handel ${ }^{9}$, het weer die vraag na vore laat kom hoe die begrip kerk verstaan moet word. Ons denke in ons kerk word hier grotendeels bepaal deur Nederlandse publikasies uit die tyd van die veertiger- en vyftigerjare. Tog word dit duidelik dat 'n studie oor die kerkbegrip van ons kerklike orde so stadigaan noodsaaklik geword het. So 'n studie kan juis in ons kerk van groot betekenis wees.

Hier kan daarop gewys word dat die debatte op die Tussenkerklike Kommissie beteken dat in ons kerk nuwe aandag gegee moes word aan ons (Hervormde) verstaan van begrippe soos die kerk, die gemeente, die verhouding tussen die plaaslike gemeente tot die algemene 
kerk asook die plek en funksie van die meerdere vergaderings in die kerk. Hier het dit duidelik geword dat in ons kerklike lewe die begrippe dikwels slordig of ongedefinieerd gebruik is ${ }^{10}$.

Dit is nogal interessant, juis rondom die hele saak van die bevoegdhede van die meerdere vergaderings om vas te stel hoe sterk die neiging in ons kerk is om die opvattings van die verenigingsreg te aanvaar soms ten koste van die standpunte soos dit deur ons reformatoriese verlede uitgespel is. So blyk dit ook dat die dienskarakter van die amp in ons kerklike denke nog nie genoeg deurgedink is nie en daarom bestaan daar soms begripsverwarrings ${ }^{11}$. In ' $n$ sekere sin het die TKK-debatte dus ' $n$ heilsame invloed op ons kerklike denke en teologie.

'n Verdere aangeleentheid wat in ons kerklike denke lank stilgelê het en waarskynlik te min aandag gekry het, is die hele vraag na die plek en funksie van die belydenisskrifte in ons Kerk. Hierdie kerkregtelike saak wat op 'n uitmuntende wyse deur Goddefroy in 1912 met sy brosjure Neen, niet Roomsch uiteengesit is, vra nou se dae weer na verdere studie en uiteensetting. Dit waarskynlik omdat daar oor die algemeen, te weinig kennis geneem word van dit wat reeds in ons kerklike kring oor hierdie saak gesê én gepubliseer is.

Dit is duidelik dat hierdie vraag, wat ook in Europa in die calvinistiese kerke aldaar vandag aan die orde is, veral vanuit die kerkordelike en kerkregtelike hoek benader moet word. Immers die predikant se ondertekening van die proponentsformule bind hom op 'n bepaalde manier aan die belydenisskrifte. Dit lyk belangrik dat die praktiese en die prinsipiële aard en effek van daardie binding weer sorgvuldig nagegaan sal word. Maar, belangriker nog as dit, is ook die vraag na die plek en die funksie van die belydenisskrif in die lewe en werk van die kerk èn in die struktuur van die kerk. Dit is tog merkwaardig hoe hierdie aangeleentheid telkens weer in die lewe van die kerk aan die orde gestel word. Miskien hang dit saam met die feit dat dit vir die mens nie maklik is om in alles hom aan die juk van Christus te onderwerp nie.

Slegs deur hierdie enkele sake aan te raak, word dit duidelik dat daar nog heelwat navorsing-, studie- en dinkwerk op die vlak van die Kerkreg, juis in ons akademiese en kerklike lewe, gedoen sal moet word. Een van die belangrikste areas, wat veral in ons tyd taamlik akuut geword het, is die probleme rondom die verhouding tussen kerk en staat, kerk en gemeenskap en kerk en die strukture van die gemeenskap. 'n Mens sou dié vrae kon saamvat onder die hoof: kerk en ekumene en dan verstaan ons onder ekumene, na aanleiding van Lk 2:1, die gesekulariseerde wêreld. Dit sluit dan ook die grootste gros van die internasionale kerklike organisasies in, want dié liggame vertoon méér ooreenkomste met die gesekulariseerde wêreld as met die liggaam van Christus. 
In ieder geval is die vraag akuut of ons vir die omskrywing van die verhouding tussen kerk en owerheid, wat ter sprake kom as oor dié tussen kerk en staat nagedink word, nog kan volstaan met artikel 36 van die Nederlandse Geloofsbelydenis. Dit dan veral in die lig van die feit dat die owerhede al lank nie meer geneë is om "die heilige Woordbediening in stand te hou" nie en ook nie om "alle afgodery en valse godsdiens teen te gaan en uit te roei, die ryk van die Antichris te vernietig en die koninkryk van Jesus Christus te bevorder" nie. In ons kerkordenende denke kom die vraag dan na vore wat dié verhoudinge dan wèl moet wees.

Die saak is in ' $n$ sekere mate belangrik omdat die huidige genitiefteologieë allerlei ideologies-bepaalde antwoorde op hierdie vrae gee en daardeur ook verwarring onder die gelowiges skep.

Die waarheid kan miskien gekonstateer word dat die vrae van die kerklike orde en regering in ons kerk betreklik min aandag trek. Dit is in skerp teenstelling met die Gereformeerde Kerk. Dit is egter verstaanbaar, want die Gereformeerde Kerk, wat die erfenis van die Nederlandse afskeiding van 1934 en die Doleansie van die tagtigerjare handhaaf, moet vanweë daardie gebeure baie aandag aan die kerk, sy orde en sy regering gee. Dit is moontlik dat uit reaksie teen daardie eensydigheid die vrae van die Kerkreg by ons betreklik min aandag kry. Dit is my mening egter dat die gebrek aan kennis oor die grondslae en inhoud van ons kerklike orde en regering ' $n$ bydrae daartoe lewer dat ons kerk, in sy verskillende geledinge, die indruk skep dat hy onseker is oor die praktiese weë wat in die huidige tyd en in die toekoms gegaan moet word.

My bemoeienis met die vak Kerkreg en die kerklike orde was nie net beperk tot die Universiteit en die hantering van dié vak in die opleiding nie. Van meet af is ek ingetrek in die werksaamhede van die Raad vir Regsadvies. Hierdie Raad wat deur die Algemene Kerkvergadering in die lewe geroep is as 'n adviesliggaam, moes deur die jare, wat ek daarmee gemoeid was, talle interessante fasette van die kerklike reg en orde behandel, ondersoek en daaroor adviese uitbring.

By die Raad en sy werksaamhede het dit duidelik geword dat die hele aangeleentheid van die kerklike orde en reg nooit die stokperdjie van 'n paar mag wees nie, maar uitdrukking is en moet wees van die vaste bane van die kerklike lewe soos Christus, ons enigste Meester, dit vir ons ingestel het. Dié ideaal, so kan mens vasstel, word in die praktyk van die kerklike lewe nie nougeset genoeg nagestreef nie.

Miskien kan ek hier, om verder te gaan, iets noem van die werk van die Raad waarmee ek gemoeid was. As eerste miskien dit dat die 1951-Kerkwet en Bepalings, ondanks al die goeie hoedanighede van hierdie orde, aanvanklik en vir jare daarna, ervaar is as ' $n$ orde wat 
van buite af aan die Kerk opgelê is. Dié Kerkwet en Bepalings het, so ver ek kon nagaan, nié voortgekom uit voortgaande studie, besinning en gesprek wat in ons Kerk oor die kerklike orde en struktuur gevoer is nie. Dit lyk veel eerder asof die kerklike vadere in die vroeë vyftigerjare nie veel meer gedoen het as om die 1950-Kerkorde van die Nederlandse Hervormde Kerk vir gebruik in ons Kerk aan te pas nie. Aansienlike leemtes in ons kerklike ordestruktuur, wat as gevolg van dié werkwyse agterna ingevul moes word, toon duidelik dat die 1951 Wet en Bepalings nie 'n ordestruktuur geskep het wat uit ons kerk gegroei het en daarom ook die werklikheid van die kerklike lewe weerspieël het nie. (In dié opsig is die jongste Wet en Bepalings alweer 'n groot verbetering.)

Hier moet vermeld word dat mnr $A B$ van $N$ Herbst, die Administrateur, wat uit hoofde van sy posisie in die kerk baie met die ordestruktuur van die kerk te make het, ook 'n groot bydrae gelewer het om die 1951 Wet en Bepalings so te herskryf en aan te vul dat dit werklik die lewe en werk van die kerk kan dien. As die jongste Wet en Bepalings met dié van 1951 vergelyk word, sal dit gou duidelik word hoeveel werk deur die Raad vir Regsadvies in die afgelope 25 jaar vermag is.

In 'n sekere sin was dit nié 'n ideale situasie nie, want dit is nie wenslik dat voortdurend aan die orde van die Kerk getimmer word nie. Dit alleen al omdat wysigings op die een plek dikwels wysigings op 'n ander plek sal veroorsaak. Tog het die 1951-Wet en Bepalings sèlf asook die vrae vanuit die daaglikse lewe van die kerk, die noodsaak om te sorg dat "die ware godsdiens onderhou en die ware leer oral versprei word en die oortreders op geestelike wyse vermaan en in toom gehou kan word" (NGB, art 30) vir die veranderings gevra. Dit is dan ook merkwaardig hoe positief die verskillende Algemene Kerkvergaderings wat die adviese van die Raad van Regsadvies moes hanteer, op hierdie vlak gereageer het.

In die loop van die arbeid wat op hierdie terrein gedoen is, het dit steeds weer geblyk hoe noodsaaklik dit is dat op hierdie terrein sorgvuldig en netjies gedink, geformuleer en geskryf sal word. Dit moet gesê word, want die algemene spraakgebruik in die Kerk is wat dit betref, dikwels slordig en onbepaald. Dit gee dikwels aanleiding tot onnodige misverstand en onenigheid. Dit word veral duidelik as daar gepraat word oor die kerkbegrip, die inhoud en omvang van die begrippe amp en diens en dergelike meer. Geleidelik het daarin wel verbetering gekom, hoewel dit baie duidelik is dat die erfenis van die 19de-eeuse verenigingsreg in ons kerkordelike denke 'n lastige oorlewingsvermoë het.

\section{AFSLUITENDE OPMERKINGS}

Uit hierdie terugblik oor die afgelope 25 jaar, het dit wel duidelik 
geword dat die Kerkreg as vakgebied nié 'n primêre rol in die opleiding speel nie. Ook in die lewe van die kerk is dit nie ' $n$ terrein wat in die sentrum van die aandag staan nie. In 'n sekere sin hang dit saam met die aard van hierdie vakgebied wat in 'n hoë mate 'n dienende rol speel, want die orde en struktuur van die kerk is nie méér as ' $n$ middel tot ' $n$ doel nie. Tog is dit jammer dat nie een of meer studente die tyd of die geleentheid kon vind om op hierdie vakgebied te promoveer nie. Die rede daarvoor mag miskien wees dat die fondamente van hierdie hele vakgebied eers weer stewig herbou moes word.

Dit sou natuurlik ' $n$ ideale toestand wees indien dit moontlik sou wees om, wat die toekoms betref, ' $n$ dosent slegs vir die Kerkreg in ons opleiding aan te stel. Indien die behoeftes van die Departement Kerkgeskiedenis as 'n geheel gesien word, lyk dit voorlopig nie moontlik dat so ' $n$ ideale toestand bereik sal word nie. Dit is nie so beswaarlik nie, want die opleiding is daar om die Kerk te dien en nie andersom nie. Dit beteken voorlopig dat die vak Kerkreg 'n hulpwetenskap op die terrein van die historiese vakke sal bly. Dit is egter wel so dat die belangrikheid van hierdie vakgebied steeds beklemtoon sal moet word sodat ons kerklike struktuur steeds ' $n$ orde sal weerspieël wat die ampte en hulle vergaderings in staat sal stel om die ware godsdiens te onderhou en die ware leer oral te versprei (art 30, N G B.)

Ten slotte, as hierdie oorsig oor wát die afgelope 25 jaar op die vakgebied van die Kerkreg in ons opleiding gebeur het van naderby gesien word, dan is dit miskien teleurstellend: 'n paar geskrifte, 'n klompie artikels en ' $n$ aantal memoranda en rapporte. Die probleem bly egter staan dat met die wye opdrag wat elke dosent aan ons opleiding ontvang dit nie maklik is om op elkeen van die afsonderlike gebiede werklik indringend besig te wees en baanbrekende werk te verrig nie. Tog kan ek net dankbaar wees dat hierdie geleentheid my gegee is en dat ek ook op hierdie interessante vakgebied die een en ander kon doen. Uiteindelik bly dit waar dat Jesus Christus aan sy dissipels gesê het (Lk 10:9-10):

"Die slaaf wat maar net sy opdrag uitgevoer het, kry mos nie dank nie, of hoe? So is dit ook met julle: As julle alles gedoen het wat aan julle opgedra is, sê dan net: Ons is maar slawe wat niks verdien nie. Ons het net gedoen wat ons verplig was om te doen."

\section{Verwysings}

1. Dit blyk baie duidelik uit die verskil tussen die Roomse en reformatoriese dogmatiese omskrywings van die begrip kerk en die daaropvolgende strukturering van die kerk.

2. Vergelyk SP Engelbrecht, Neo-Calvinisme, Ontwikkeling of afwyking, Pretoria 1945 
na aanleiding van JV Coetzee, Neo-Calvinisme. Verbastering of regte ontwikkeling. In sy Inleiding gee Engelbrecht 'n oorsig van die geskil en trek hy ook, kerkregtelik gesproke, duidelike grense tussen sy standpunt en dié van die Doleansiekerkreg wat deur JV Coetzee na vore gebring word.

3. Dit wil sê die kerkregtelike opvattings wat deur A Kuyper, FL Rutgers en hulle medestanders en opvolgers gepropageer is.

4. Vergelyk onder andere Hervormde Teologiese Studies, Inhoudsopgawe van Jaargange 1-35, HTS $198036,1-2$.

5. Ek verwys hier, sonder om nou teks en kapittel ook te noem, na die studie en arbeid van persone soos PJ Kromsigt, G Oorthuys, Th L Haitjema, AA van Ruler, GN Lekkerkerker, AJ Bronkhorst en nog ander wat in Nederland uitgeloop het op die aanvaarding van die kerkorde van 1950 .

6. Vergelyk byvoorbeeld Sohm (1892: 455-9) wat meen dat daar ' $n$ inherente teenspraak is tussen die begrippe kerk en reg.

7. In die NG Kerk het hierdie vrae veral na vore gekom in die tyd toe daar aandag gegee is aan die instelling van 'n Algemene Sinode nadat besluit is om die federale struktuur van provinsiale kerke met ' $n$ eenheidstruktuur te vervang. Hier kan veral gelet word op die werke van Jonker (1965) en Keet (1963). In die Gereformeerde Kerk kan veral verwys word na die werke van Van der Linde (1965) en Kruger e a (1966). Op die oomblik is 'n nuwe Handleiding, opgestel deur GPL van der Linde, by die pers. In hierdie verband het A le $R$ du Plooy heelwat werk gedoen oor die Skriftuurlike basis van die kerklike orde.

8. Hier kan veral gedink word aan die drie, mees opspraakwekkende gevalle, naamlik dié ten opsigte van ds AJ Begemann, ds CJL Ruysch van Dugteren en prof AS Geyser.

9. 'n Uittreksel hiervan is my brosjure Opsig en tug met verwysing na die afsnyding deur die ban, Pretoria 1973.

10. So word die begrippe Algemene Kerkvergadering en Kerk dikwels as sinonieme van mekaar gebruik, terwyl die verhouding plaaslike gemeente - algemene kerk glad nie so helder is as wat algemeen aanvaar word nie. Soms word selfs, as reaksie teen die Doleansie-kerkreg, die verantwoordelikheid van die plaaslike gemeente heeltemal ontken. Die erfenis wat uit die verenigingsreg kom, besit 'n onnodige taai lewenskragtigheid maar dit gebeur omdat die grondslae van ons kerklike orde nie genoeg waardeer of geken word nie.

11. Sommige van hierdie sake word in ' $n$ bietjie meer besonderhede behandel in my artikel "Kerk en struktuur", HTS 38/1, 1-22.

\section{Literatuurverwysings}

Engelbrecht, SP 1945. Neo-Calvinisme. Ontwikkeling of afwyking. Pretoria.

Jonker, WD s.a. En as jou broer sondig. Pretoria.

Jonker, WD 1965. Om die regering van Christus in sy kerk. Pretoria.

Jooste, JP 1964. Die verhouding tussen kerk en staat aan die Kaap tot die helfte van die negentiende eeu. Bloemfontein.

Keet, BB 1963. Orde in die kerk. Kaapstad/Pretoria.

Kleijn, HG 1888. Algemeene kerk en plaatselijke gemeente. Dordrecht.

Kleynhans, EPJ 1973. Die kerkregtelike ontwikkeling van die Nederduitse Gereformeerde Kerk in Suid-Afrika, 1795-1962. Stellenbosch.

Kleynhans, EPJ 1982. Gereformeerde kerkreg. Deel I. Pretoria.

Kruger, LS e.a. 1966. Handleiding by die Kerkorde van die Gereformeerde kerke in SuidAfrika. Potchefstroom.

Milner, BC 1970. Calvin's doctrine of the church. Leiden.

Niesel, W s.a. Bekenntnisschriften und Kirchen $=$ ordnungen der nach Gottes Wort reformierten kirchen. Zollikon-Zürich.

Plomp, J 1969. De Kerkelijke tucht bij Calvijn. Kampen.

Pont, AD 1973. Opsig en tug met verwysing na die afsnyding deur die ban. Pretoria.

Pont, AD 1981. Die historiese agtergronde van ons kerklike reg. Deel I. Pretoria.

Pont, AD [1982]. Kerk en struktuur, HTS 38/1, 1-22. 
Sadler, TNH 1978. Die kerklike tughandeling. Universiteit van Pretoria. (Ongepubliseerde DD-proefskrif).

Sohm, R 1982. Kirchenrecht. Teil I. Leipzig.

Van der Linde, GPL 1965. Grondbeginsels van die presbiteriale kerkregeringstelsel. Potchefstroom.

Van der Watt, PB 1973. Die Loedolff-saak en die Nederduitse Gereformeerde Kerk 1862-1962. Kaapstad.

Van Staden, FAH 1973. Kerkorde in die geskiedenis van die Nederduitse Gereformeerde Kerk in Suid-Afrika 1652-1970. Universiteit van Pretoria. (Ongepubliseerde DDproefskrif).

Van 't Spijker, W 1970. De ambten bij Martin Bucer. Kampen.

Visser, J 1982. Die tug oor die ampsdraers. Potchefstroomse Universiteit vir CHO. (Ongepubliseerde D Th-proefskrif).

Vorster, JD 1965. Die kerkregtelike ontwikkeling van die Kaapse Kerk onder die Kompanjie, 1652-1795. Potchefstroom. 